\begin{tabular}{l}
\hline SPORTIVE: Journal of Physical Education, Sport and Recreation \\
Volume 3 Nomor 1 September 2019 \\
e-ISSN: 2597-7016 dan p-ISSN: $2595-4055$ \\
@) (1) This work is licensed under a Creative Commons Attribution \\
4.0 International License
\end{tabular}

\title{
Hubungan Antara Kekuatan Otot Lengan Dan Keseimbangan Dengan Kemampuan Hand Stand Dalam Senam Lantai
}

\author{
La Kamadi ${ }^{*}$
}

\section{Keywords :}

Kekuatan Otot Lengan,

Keseimbangan, Hand Stand,

Senam Lantai.

\section{Corespondensi Author}

${ }^{1}$ Universitas Negeri Makassar,

Email: la.kamadi@unm.ac.id

\section{Article History}

Received: 20-07-2019;

Reviewed: 26-07-2019

Accepted: 11-08-2019;

Published: 29-09-2019

\begin{abstract}
ABSTRAK
Penelitian ini bertujuan untuk mengetahui hubungan kekuatan otot lengan dan keseimbangan dengan kemampuan hand stand dalam senam lantai pada siswa SD Negeri 3/77 Lamurukung. Penelitian ini termasuk jenis penelitian deskriptif. Populasi penelitian ini adalah seluruh siswa SD Negeri 3/77 Lamurukung Kabupaten Bone dengan jumlah sampel penelitian 60 orang siswa putra yang dipilih secara random sampling. Teknik analisis data yang digunakan adalah teknik analisis korelasi dan regresi dengan menggunakan sistem SPSS Versi 11.00 pada taraf signifikan 95\% atau $\alpha 0$ 0,05. Bertolak dari hasil analisis data, maka penelitian ini menyimpulkan bahwa: Ada hubungan kekuatan otot lengan dengan kemampuan hand stand dalam senam lantai, terbukti nilai ro $=$ 0,773 ( $P<\alpha$ 0,05); Ada hubungan keseimbangan dengan kemampuan hand stand dalam senam lantai, terbukti nilai ro $=$ $0,628(P<\alpha 0,05)$ dan; Ada hubungan antara kekuatan otot lengan dan keseimbangan dengan kemampuan hand stand dalam senam lantai, terbukti nilai $R o=0,773(P<\alpha 0,05)$.
\end{abstract}

\section{PENDAHULUAN}

Siswa adalah individu yang sedang tumbuh dan berkembang. Sebagai mahluk sosial mempunyai sifat ketergantungan dengan orang lain, begitupula dengan lingkungan tempat tinggalnya. Tingkat kesegaran jasmani dan perkembangan fisik seseorang berbeda-beda, begitu pula tingkat kemampuan tubuhnya walaupun berada pada tingkat usia yang sama.

Senam yang dikenal dalam bahasa Indonesia sebagai salah satu cabang olahraga, merupakan terjemahan langsung dari bahasa Inggris yaitu Gymnastic atau bahasa Belanda Gymnastiek. Gymnastic sendiri didalam bahasa asliinya berasal dari bahasa Yunani, Gymnos yang berarti telanjang. Senam dapat diartikan sebagai bentuk latihan tubuh pada lantai atau padda alat yang dirancang untuk meningkatkan daya tahan, kekuatan, kelentukan, kelincahan, dan koordinasi, serta kontrol tubuh. Senam artistik adalah sebagai senam yang menggabungkan aspek tumbling dan akrobatik yang dilakukan pada alat lantai (floor exervcise), kuda lomat (voulting horse), palang sejajar (parallel bars), dan palang tunggal (horizontal bar). Senam artistik yang diberikan di SD merupakan dasar senam lantai, dengan bentuk latihan dasar seperti roll ke depan. Dalam senam lantai, seorang pesenam tidak akan mampu melakukan keterampilan senam dengan baik, jika ia tidak memiliki keseimbangan dan kelentukan yang diperlukan ddalam gerakan roll ke depan dalam senam latai.

Oleh karena itu, untuk berhasilnya pembelajaran senam di sekolah, siswa perlu dibekali dengan seperangkat kualitas fisik 
seperti keseimbangan dan kelentukan yang diperlukan untuk melakukan keterampilan senam. Pendidikan jasmani dan kesehatan di sekolah dasar bertujuan membantu siswa dalam meningkatkan dan memperbaiki derajat kesehatan dan kesegaran jasmanni melalui pengertian pengembangan, sikap positif dan keterampilan gerak dasar serta berbagai aktifitas jasmani. Salah satu bagian dalam pelaksanaan kegiatan belajar mengajar pendidikan jasmani di SD diberikan pelajaran senam, terutama senam lantai. Cabang olahraga senam kurang pesat perkembangannya dibanding dengan cabangcabang olahraga lainnya. ini disebabkan karena selain kurangnya sebagian guru menguasai gerakan-gerakan senam juga kurangnya sarana dan prasarana yang menunjang. Olahraga senam perlu ditingkatkan dan disebarluaskan di seluruh pelosok tanah air didalam rangka usaha memasyarakatkan olahraga dan mengolahragakan masyarakat untuk mencapai keseimbangan antara pertumbuhan jasmani dan perkembangan rohani. Berdasarkan pengamatan tersebut, telah mendorong penulis untuk mengembangkan senam khususnya gerakangerakan senam lantai pada tiingkat sekolah dasar.

Senam lantai merupakan salah satu rumpun senam. Disebut senaml antai, karena gerakan senam dilakukan dimatras. Senam lantai disebut juga dengan istilah latihan bebas, karena saat melakukannya tidak menggunakan benda atau perkakas lain (alat lain). Bergerak dengan cara membulatkan badan sedemikian rupa sehingga badan dapat bergerak berguling seperti benda bulat. Dalam senam lantai berguling atau disebut roll dapat dilakukan dua cara yakni roll ke depan dan roll ke belakang, namun pada penelitian ini berfokus pada roll ke depan. Namun untuk menguasai gerakan senam lantai dengan baik dan sempurna tidaklah mudah. Hal ini diduga karena kurangnya beberrapa hal yang dapat mempengaruhi prestasi yaitu faktor terbentuknya keseimbangan badan dan kelentukan.

Keseimbangan adalah kemampuan untuk mempertahankan sikap tubuh yang tepat pada saat melakukan gerakan. Gallahue (1976:223) mengatakan bahwa : "Keseimbangan merupakan aspek dasar dari segala gerakan. Max Jones (1985:12) mengatakan bahwa : "Ada dua jenis keseimbangan yaitu keseimbangan dinamis dan keseimbangan statis". Keseimbangan dinamis adalah kemampuan untuk memelihara keseimbangan selama bergerak dan penuh dengan semangat. Sedangkan keseimbangan statis adalah kemampuan untuk memelihara keseimbangan dalam posisi yang tidak berubah, misalnya berdiri pada satu kaki. Keseimbangan juga merupakan kemampuan untuk menguasai gerak alat tubuh. Keseimbangan mencegah seseorang jatuh bila pola berjalan yang sedang dilakukan terganggu. Sejalan dengan itu Moch. Sajoto (1988:18) mengatakan bahwa : Keseimbangan adalah kemampuan seseorang mengendalikan organ-organ syaraf otot, seperti hand stand atau dalam mencapai keseimbangan sewaktu berjalan kemudian terganggu. Di dalam bidang olahraga banyak hal yang harus dilakukan atlet dalam masalah keseimbangan ini, baik dalam menghilangkan ataupun mempertahankan keseimbangan. Selanjutnya Harsono (1988:223) mengemukakan sebagai berikut: Balance atau keseimbangan adalah kemampuan untuk mempertahankan sistem neuromuscler kita dalam kondisi statis atau mengontrol sistem neuromuscular tersebut dalam suatu posisi atau sikap yang efesien selagi kita bergerak. Sehubungan dengan itu, maka keseimbangan badan sangat penting pada pelaksanaan roll ke depan pada cabang olahraga senam. Karena apabila seseorang melakukan roll ke depan, maka dia akan jongkok kemudian sikap posisi kepala di bawah atau melakukan roll, maka dia harus menjaga keseimbangan badannya agar tidak jatuh. Oleh karena itu, maka yang dimaksud dengan keseimbangan dalam penelitian ini adalah kemampuan seseorang dalam mengendalikan organ-organ tubuhnya pada saat melakukan aktivitas.

Keseimbangan badan dan kelentukan yang baik adalah unsur-unsur yang potensil yang dapat menentukan keberhasilan ddalam pembinaan prestasi. Unsur tersebut perlu dikembangkan, karena dapat menunjang tercapainya peningkatan prestasi senam. Keseimbangan dan kekuatan otot lengan yang dimiliki bagi setiap atlet akan berpengaruh dalam melaksanakan setiap proses gerakangerakan senam. Keseimbangan badan dan keuatan otot lengan dapat dihubungkan dengan berbagai gerakan-gerakan senam untuk peningkatan prestasi secara optimal. Namun untuk meningkatkan prestasi atlet sering mengalami hambatan oleh karena kurangnya keseimbangan dan kekuatan otot lengan. Seorang atlet yang memiliki atau menguasai keseimbangan dan kekuatan otot lengan yang baik dan sempurna, akan dapat melakukan gerakan senam dengan baik. Sebaliknya atlet 
yang tidak memiliki keseimbangan dan kekuatan otot lengan yang baik, akan sulit melakukan gerakan senam dengan sempurna. Untuk itu sebagai guru olahraga dan pelatih senam perlu memahami pentingnya keseimbangan dan kekuatan otot lengan khususnya senam lantai.

Salah satu komponen yang harus dimiliki oleh seorang atlet bola adalah kekuatan, kekuatan merupakan daya penggerak setiap aktivitas fisik disamping itu memegang peranan penting dalam melindungi atlet dari kemungkinan cedera dan dapat membantu stabilitas sendi-sendi. Kekuatan adalah kemampuan otot untuk membangkitkan tegangan suatu tahanan. Kekuatan adalah kemampuan kondisi fisik yang menyangkut kemampuan seorang atlet pada saat mempergunakan otot-otot yang menerima beban dalam waktu tertentu. Kekuatan otot adalah kemampuan untuk pengembangan tenaga maksimum dalam kontraksi yang maksimal untuk mengatasi tahanan atau beban. Kekuatan sangat penting dalam menunjang aktivitasaktivitas olahraga seperti roll ke depan. Dalam cabang olahraga senam pada roll ke depan, meskipun diperlukan kelentukan, keseimbangan, koordinasi dan sebagainya, akan tetapi komponen kondisi fisik tersebut di atas haruslah ditunjang oleh kekuatan. Sebagaimana yang dikemukakan oleh Harsono (1988:177) bahwa: "Kekuatan tetap merupakan basis dari semua komponen kondisi fisik". Jadi dengan memiliki kekuatan, maka komponen kondisi fisik lainnya dapat dikembangkan sesuai kebutuhan.

Pada roll ke depan, kekuatan otot yang digunakan dalam melakukan gerakan mengguling adalah kekuatan otot dinamis, dimana sektor otot berperan untuk memindahkan posisi suatu benda dari satu tempat ke tempat yang lain. Kontraksi otot ini digunakan untuk menghasilkan tenaga eksternal untuk menggerakkan anggota tubuh. Kekuatan adalah tenaga yang dipakai untuk mengubah keadaan gerak atau bentuk dari suatu benda. Gerakan mendorong atau menarik dapat mengakibatkan suatu benda bergerak atau berubah arah, tergantung besarnya kekuatan dan sifat fisik dari benda yang digerakkan. Lengan adalah salah satu anggota gerak tubuh bagian atas atau disebut juga dengan "extremitas superior" yang mana terdiri dari lengan atas dan lengan bawah. Dengan demikian kekuatan otot lengan meliputi pengukuran yang bersumbu pada persendian siku (articulatio cubiti), persendian pergelangan tangan (articulatio carpalialis), dan persenidan pada telapak tangan (articulatio metta carpalialis), namun yang menjadi permasalahan pokok dalam penelitian ini adalah kekuatan otot lengan yang bersumbu pada persendian siku yakni gerakan ekstensi. Dengan demikian sasaran yang dituju adalah kerja otot triceps secara maksimal dalam kaitannya dengan kemampuan roll ke depan pada cabang olahraga senam di nomor lantai.

Pada dasarnya unsur kekuatan otot lengan sangat dibutuhkan pada semua cabang olahraga, kekuatan menunjukkan kualitas gerak. Atlet yang memiliki kekuatan yang baik, akan menggunakan tubuhnya secara efektif, dibandingkan dengan atlet yang kekuatannya kurang baik pada suatu gerakan senam. Setiap pesenam membutuhkan kemampuan kekuatan otot lengan, terutama dalam gerakan roll ke depan dalam senam lantai. Kekuatan otot lengan sangat dibutuhkan atau penting dalam usaha peningkatan prestasi senam, dengan demikian perlu mendapat perhatian untuk menghindari kesalahan pemberian latihan setiap atlet, kesalahan dalam pemberian latihan sangat berpengaruh pada peningkatan prestasi.

\section{METODE}

Metode yang dipergunakan dalam penelitian ini adalah metode deskriptif. Variabel penelitian yang diteliti dalam penelitian ini terdiri atas: variabel bebas yaitu keseimbangan badan dan kekuatan otot lengan, sedangkan variabel terikat yaitu kemampuan roll ke depan. Desain penelitian atau rancangan penelitian yang digunakan dalam penelitian ini adalah korelasional. Setiap penelitian tentunya selalu menggunakan obyek untuk diteliti atau diistilahkan dengan populasi. Populasi adalah keseluruhan dari individu yang dijadikan obyek penelitian. Populasi suatu penelitian harus memiliki karakteristik yang sama atau hampir sama. Olehnya itu yang menjadi populasi pada penelitian ini adalah seluruh Siswa SD Negeri 2 Manurunge Kabupaten Bone. Sampel secara sederhana diartikan sebagai bagian dari populasi yang menjadi sumber data yang sebenarnya dalam satu penelitian. Sampel yang diambil atau digunakan dalam penelitian ini berjumlah 60 orang dari siswa SD Negeri 2 Manurunge Kabupaten Bone dengan teknik pengambilan sampel proporsive random sampling. Data yang dikumpulkan dalam penelitian ini meliputi : Tes keseimbangan, kekuatan otot lengan, dan kemampuan roll ke depan. Data yang terkumpul tersebut perlu dianalisis secara statistik 
deskriptif, maupun infrensial untuk keperluan pengujian hipotesis penelitian. Adapun gambaran yang digunakan dalam penelitian dengan menggunakan uji korelasi dan regresi.

HASIL DAN PEMBAHASAN
Analisis deskriptif data penelitian yang terdiri dari nilai tes keseimbangan badan dan kekuatan otot lengan dengan kemampuan roll ke depan pada cabang olahraga senam dapat dilihat dalam rangkuman hasil analisis deskriptif yang tercantum pada tabel.

Tabel 1. hasil analisis deskriptif data.

\begin{tabular}{cccc}
\hline $\begin{array}{c}\text { Hipotesis } \\
\text { Statistik }\end{array}$ & Keseimbangan & Kekuatan otot lengan & $\begin{array}{c}\text { Kemampuan roll ke } \\
\text { depan }\end{array}$ \\
\hline $\mathrm{N}$ & 60 & 60 & 60 \\
$\mathrm{X}$ & 4162 & 917 & 415 \\
$\mu$ & 69,3667 & 10,2833 & 6,9167 \\
$\mathrm{Sd}$ & 5,95169 & 1,63740 & 1,35661 \\
Min & 60 & 6 & 5 \\
Max & 80 & 13 & 9 \\
Range & 20 & 7 & 4 \\
\hline
\end{tabular}

Suatu data penelitian yang akan dianalisis secara statistik harus memenuhi syarat-syarat analisis. Untuk itu setelah data keseimbangan dan kekuatan otot lengan dengan kemampuan roll ke depan pada cabang olahraga senam dalam penelitian ini terkumpul, maka sebelum dilakukan analisis statistik untuk pengujian hipotesis, terlebih dahulu dilakukan uji persyaratan yaitu normalitas dengan uji Kolmogorov-Simirnov Test. Dari hasil uji Kolmogorov-Smirnov Test yang dilakukan, diperoleh hasil sebagaimana yang terlampir. Untuk hasil perhitungan dapat dilihat pada tabel rangkuman berikut :

Tabel 2. hasil uji normalitas data

\begin{tabular}{clccc}
\hline No & \multicolumn{1}{c}{ Variabel } & Probabilitas & $\boldsymbol{\alpha}$ & Keterangan \\
\hline 1 & Keseimbangan badan & 0,184 & 0,05 & Normal \\
2 & Kekuatan otot lengan & 0,123 & 0,05 & Normal \\
3 & Kemampuan roll ke depan & 0,162 & 0,05 & Normal \\
\hline
\end{tabular}

Analisis korelasi dilakukan untuk mengetahui hubungan tiap-tiap variabel bebas dengan variabel terikat. Analisis korelasi yang digunakan adalah analisis korelasi tunggal $(\mathrm{r}$ ) dan korelasi ganda ( $\mathrm{R}$ ) pada taraf signifikan 95\%. Hasil-hasil analisis korelasi secara lengkap dapat dilihat pada tabel sebagai berikut:

Tabel 3. Hasil analisis korelasi dan regresi

\begin{tabular}{llllllll}
\hline Hipotesis & N & r/R & Rs & F & Sig. \\
\hline
\end{tabular}




\begin{tabular}{lccccc}
\hline $\begin{array}{l}\text { Korelasi keseimbangan badan } \\
\text { dengan kemampuan roll ke depan } \\
\text { pada cabang olahraga senam }\end{array}$ & 60 & 0,739 & 0,546 & - & 0,000 \\
$\begin{array}{l}\text { Korelasi kekuatan otot } \\
\begin{array}{l}\text { lengandengan kemampuan roll ke } \\
\text { depan pada cabang olahraga senam }\end{array}\end{array}$ & 60 & 0,644 & 0,415 & - & 0,000 \\
$\begin{array}{l}\text { Korelasi antara keseimbangan } \\
\text { badan dan kekuatan otot } \\
\begin{array}{l}\text { lengandengan kemampuan roll ke } \\
\text { depan pada cabang olahraga senam }\end{array}\end{array}$ & 60 & 0,751 & 0,564 & 36,844 & 0,000 \\
\hline
\end{tabular}

Pengujian hipotesis dilakukan dengan menggunakan analisis koefesien korelasi (r) dan regresi (R) pada taraf signifikan 95\%. Hal tersebut dimaksudkan untuk menganalisis hubungan antara keseimbangan dan kekuatan otot lengan dengan kemampuan roll ke depan pada cabang olahraga senam. Adapun hipotesis yang diuji kebenarannya pada penelitian ini, sebagai berikut :

\section{Hipotesis pertama}

Ada hubungan keseimbangan dengan kemampuan roll ke depan pada cabang olahraga senam. Berdasarkan hasil pengujian analisis korelasi data keseimbangan dengan kemampuan roll ke depan pada cabang olahraga senam. Diperoleh nilai korelasi $\left(\mathrm{r}_{0}\right)=0,739$ dengan tingkat Probablititas $0,000<\alpha=0,05$, untuk nilai koefesien determinasi $=0,546$. Hal ini berarti 54,6\% kemampuan roll ke depan pada cabang olahraga senam dijelaskan oleh keseimbangan badan pada siswa SD Negeri 2 Manurunge Kabupaten Bone. Sedangkan sisanya $(100 \%-54,6 \%=45,4 \%)$ dijelaskan oleh sebab-sebab yang lain. Maka Ho ditolak dan H1 diterima. Dengan demikian ada hubungan yang signifikan keseimbangan badan dengan kemampuan roll ke depan pada cabang olahraga senam pada siswa SD Negeri 2 Manurunge Kabupaten Bone.

\section{Hipotesis kedua}

Ada hubungan kekuatan otot lengan dengan kemampuan roll ke depan pada cabang olahraga senam. Berdasarkan hasil pengujian analisis korelasi data kekuatan otot lengan dengan kemampuan roll ke depan pada cabang olahraga senam. Diperoleh nilai korelasi $\left(\mathrm{r}_{0}\right)=0,644$ dengan tingkat Probablititas $0,000<\alpha=0,05$, untuk nilai koefesien determinasi $=0,415$. Hal ini berarti $41,5 \%$ kemampuan roll ke depan pada cabang olahraga senam dijelaskan oleh kekuatan otot lenganpada siswa SD Negeri 2 Manurunge Kabupaten Bone. Sedangkan sisanya $(100 \%-41,5 \%=58,5 \%)$ dijelaskan oleh sebab-sebab yang lain. Maka Ho ditolak dan H1 diterima. Dengan demikian ada hubungan yang signifikan kekuatan otot lengan dengan kemampuan roll ke depan pada cabang olahraga senam pada siswa SD Negeri 2 Manurunge Kabupaten Bone.

\section{Hipotesis ketiga}

Ada hubungan keseimbangan dan kekuatan otot lengan dengan kemampuan roll ke depan pada cabang olahraga senam. Berdasarkan hasil pengujian analisis regresi data keseimbangan dan kekuatan otot lengandengan kemampuan roll ke depan pada cabang olahraga senam. Diperoleh nilai regresi $\left(\mathrm{R}_{0}\right)=0,751$ dengan tingkat Probablititas $0,000<\alpha=0,05$, untuk nilai $R$ Square (koefesien determinasi) $=0,564$. Hal ini berarti 56,4\% kemampuan roll ke depan pada cabang olahraga senam dijelaskan oleh keseimbangan dan kekuatan otot lenganpada siswa SD Negeri 2 Manurunge Kabupaten Bone. Sedangkan sisanya $(100 \%-56,4 \%=$ 43,6\%) dijelaskan oleh sebab-sebab yang lain. Dari uji Anova atau F test, didapat F hitung adalah 36,844 dengan tingkat signifikansi 0,000 . Oleh karena probabilitas $(0,000)$ jauh lebih kecil dari 0,05 , maka model regresi dapat dipakai untuk memprediksi kemampuan roll ke depan pada cabang olahraga senam (dapat diberlakukan untuk populasi dimana sampel diambil). Maka Ho ditolak dan H1 diterima atau koefesien regresi signifikan, atau keseimbangan dan kekuatan otot 
lenganbenar-benar berpengaruh secara signifikan dengan kemampuan roll ke depan pada cabang olahraga senam. Dengan demikian ada hubungan yang signifikan antara keseimbangan dan kekuatan otot lengan dengan kemampuan roll ke depan pada cabang olahraga senam pada siswa SD Negeri 2 Manurunge Kabupaten Bone.

\section{Pembahasan}

Hipotesis pertama; ada hubungan yang signifikan keseimbangan badan dengan kemampuan roll ke depan pada cabang olahraga senam pada siswa SD Negeri 2 Manurunge Kabupaten Bone. Terbukti dari hasil analisis diperoleh nilai korelasi observasi lebih besar dari nilai korelasi tabel. Kemampuan roll ke depan dapat dirangkai dengan baik bilamana ditunjang adanya kemampuan fisik seperti keseimbangan badan. Keseimbangan badan sangat dibutuhkan untuk menjaga posisi badan guna menstabilkan rangkaian gerakan roll ke depan

Hipotesis kedua; ada hubungan yang signifikan kekuatan otot lengan dengan kemampuan roll ke depan pada cabang olahraga senam pada siswa SD Negeri 2 Manurunge Kabupaten Bone. Terbukti dari hasil analisis diperoleh nilai korelasi observasi lebih besar dari nilai korelasi tabel. Apabila penelitian ini dikaitkan dengan teori dan kerangka pikir yang mendasarinya, maka pada dasarnya hasil penelitian ini mendukung dan memperkuat teori yang sudah ada. Seperti sudah dikemukakan sebelumnya bahwa kekuatan otot lengan adalah kemampuan suatu lengan untuk melakukan tegangan terhadap tahanan. Kekuatan otot lengan dimanfaatkan pada saat posisi lengan bertumpu untuk mempertahankan titik berat badan pada awal gerakan.

Hipotesis ketiga; ada hubungan yang signifikan keseimbangan dan kekuatan otot lengan dengan kemampuan roll ke depan pada cabang olahraga senam pada siswa SD Negeri 2 Manurunge Kabupaten Bone. Terbukti dari hasil analisis diperoleh nilai probabilitas lebih kecil dari 0,05. Kemampuan atlet atau siswa di saat melakukan gerakan roll ke depan adalah bagaimana gerakan tersebut dapat terangkai dengan indah dan tidak terjadi kesalahan yang fatal. Sebab gerakan roll ke depan yang dilakukan akan melibatkan kepala untuk ditundukkan kemudian posisi pantat yang lebih tinggi selanjutnya kaki jinjit dan terakhir adalah tangan yang harus dibengkokkan untuk menjatuhkan badan dengan gulungan badan yang halus. Oleh karena itu dengan adanya keseimbangan dan kekuatan otot lengan, gerakan yang dilakukan akan lebih baik. Sebab gerakan yang dilakukan dalam posisi yang tidak stabil dengan adanya perubahan arah posisi yang selanjutnya kembali dengan posisi yang lebih sempurna. Demikian juga halnya pada kekuatan otot lengan, disaat gerakan posisi kepala di bawah tentunya pantat akan lebih diatas. Oleh karena itu dengan adanya kekuatan otot lengan akan memperlihatkan gaya untuk mempertahankan titik berat badan saat gerakan sikap roll yang lebih baik. Dengan demikian kedua komponen yang dijadikan bahan penelitian ini, memiliki keterkaitan atau sangat berhubungan dengan kemampuan roll ke depan pada cabang olahraga senam.

\section{SIMPULAN DAN SARAN}

Setelah melakukan penelitian tentang masalah hubungan kecepatan lari, kekuatan dan daya ledak dengan kemampuan roll ke depan pada cabang olahraga senam siswa SD Negeri 2 Manurunge Kabupaten Bone dengan mendapatkan hasil yang telah dibahas, maka di tarik kesimpulan sebagai berikut:

1. Ada hubungan yang signifikan keseimbangan dengan kemampuan roll ke depan pada cabang olahraga senam siswa SD Negeri 2 Manurunge Kabupaten Bone.

2. Ada hubungan yang signifikan kekuatan otot lengan dengan kemampuan roll ke depan pada cabang olahraga senam siswa SD Negeri 2 Manurunge Kabupaten Bone.

3. Ada hubungan yang signifikan antara keseimbangan dan kekuatan otot lengan dengan kemampuan roll ke depan pada cabang olahraga senam siswa SD Negeri 2 Manurunge Kabupaten Bone.

\section{DAFTAR RUJUKAN}

Arikunto Suharsini. 1992. Prosedur Penelitian Suatu pendekatan praktek. Jakarta : PT. Rhineka Cipta.

Bompa, Tudor O., 1983. Theory and Methodology of Training. Dubuque : Kendal/Hunt Publishing Company

Dwijonowinoto Kasiyo, 1993. Dasar-Dasar Ilmiah Kepelatihan. IKIP : Semarang.

Harsono. 1988. Coaching dan aspek-aspek psikologi dalam coaching. Jakarta : Penerbit Departemen Pendidikan dan kebudayaan Proyek Pengembangan Pendidikan Tinggi. 
Johnson, Barry L, Nelson, Jack K,. 1986. Practical Measurements for Evaluation in Physical Education. Minneapolis, Minnesota : Burgess Publishing Company.

Kerlinger, Fred N,. 1995. Asas-Asas Penelitian Behavioral Edisi Ketiga. Yogyakarta : Gajah Mada University Press.

Kosasih, Engkos. 1985. Olahraga dan Kesehatan. Jakarta : Tiga Serangkai.

Lutan, Rusli. 1988. Belajar Keterampilan Morotik: Pengantar Teori dan Metode. Jakarta : Dirjen Dikti Depdikbud

Nossek. 1982. General theory of training. Penerbit PAN African Press Ltd Longus.

Pinayungan,. 1987. Senam untuk Sekolah Dasar. Jakarta : Dirjen Pendidikan Dasar dan Menengah, Depdikbud.

Rahantoknam, Edward B. 1988. Belajar Motorik; Teori dan Aplikasinya dalam Pendidikan Jasmani dan Olahraga. Jakarta : P2LPTK. Dirjen Dikti Depdikbud.

Rani, Abd. Adib,. 1989. Tinjauan Analisis pada Penelitian Terapan dan Psikologi Olahraga. Ujung Pandang : FPOK IKIP.

Sajoto, Moch. 1988. Pembinaan kondisi fisik dalam olahraga. Jakarta : Departemen Pendidikan dan Kebudayaan Dirjen Dikti.

Sugiyono. 2000. Statistika untuk penelitian. Bandung : Penerbit Alfabeta. 